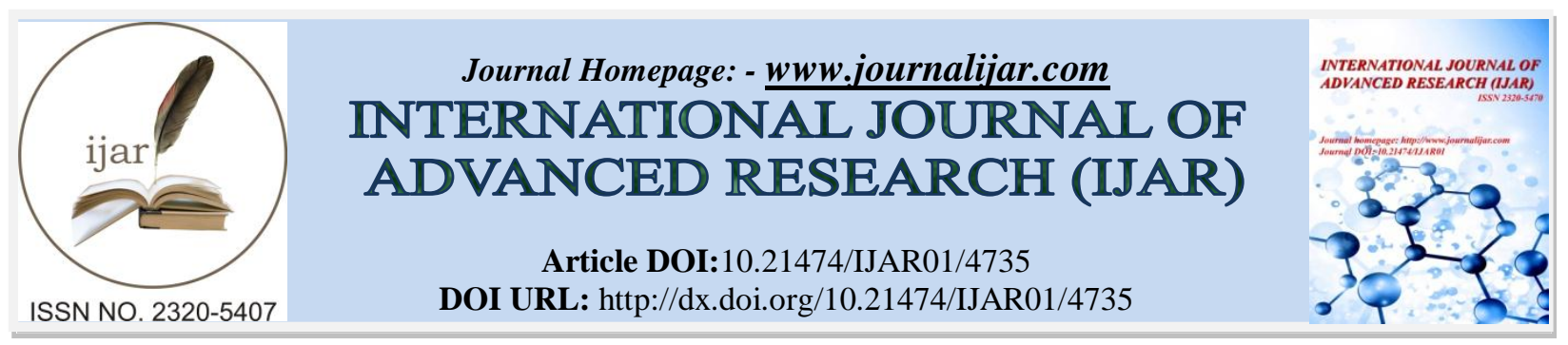

RESEARCH ARTICLE

\title{
SOIL PHYSICAL PROPERTIES OF COLD DESERT REGION OF DIFFERENT LAND USES IN NORTH
} WESTERN HIMALAYAS, H.P-INDIA.

\author{
Ravinder Kumar ${ }^{1}$, S.S.Paliyal ${ }^{2}$ and Sanjay Kumar Sharma ${ }^{3}$. \\ 1. Ph. D Doctoral Scholar, Department of Soil Science H.P. KrishiVishavavidyala, Palampur 176062, India. \\ 2. Principle Scientist, (Soil Science) KrishiVigyan Kendra, Sirmour at Dhaulakuan (H.P.) 173031. \\ 3. Principle Scientist, (Soil Science) H.P. KrishiVishavavidyala, Palampur176062, India.
}

\section{Manuscript Info}

Manuscript History

Received: 4 May 2017

Final Accepted: 6 June 2017

Published: July 2017

Key words:-

Arid soil, physical properties, North Western Himalaya

\section{Abstract}

To study the soil physical properties of cold arid zone of different land uses in North -Western Himalayas, H.P, Global positioning system (GPS) 71 representative surface $(0-15 \mathrm{~cm})$ and subsurface $(15-$ $30 \mathrm{~cm}$ ) soil samples were collected randomly from cultivated and pasture lands using stainless steel spatula, shovel and spade. The surface, sub surface were analysed for physical properties viz. Soil $\mathrm{pH}$, soil texture, bulk density, water holding capacity, The soils were found sandy loam to sandy clay loam in texture and slightly alkaline in their reaction $(\mathrm{pH}$ 7.7-8.1). Sand increased with increase in soil depth whereas silt and clay decreased with increasing soil depths. Pasture lands were found to have comparatively lower WHC as compared to cultivated lands (annual crops) because of higher clay and organic matter content in cultivated lands (annual crops).

Copy Right, IJAR, 2017,. All rights reserved.

\section{Introduction:-}

Arid and semiarid zones cover approximately $40 \%$ of the land surface, with a continuous increase in the area by desertification processes, induced mainly by anthropogenic activities and/ or climatic change. The process of desertification affects the world at ecological, economic and social levels (Salih, 1998). Soils of arid and semiarid zones are very susceptible of water erosion (Cornelis, 2006) mostly due to the scarce vegetation cover, low organic matter content and the small resistance to the erosion forces. The magnitude of water erosion also depends on their texture, water content, evaporation, percolation and lixiviation. These soil characteristics are not favorable to the resistance of the soil to water erosion (D’Odorico and Porporato, 2006). In terms of soil orders, typical arid and semiarid zone soils around the world include Aridosol, Alfisols, Entisols, Molisols, and Vertisols (Dregne, 1976). In arid areas, soils with little or no vegetation cover are exposed to torrential precipitation events, which are characterized by short durations and high intensities, and are prompt to the occurrence of physical and chemical processes that change the surface layer conditions, such as surface sealing and crusting. When the surface is dry, a hard layer is formed (crust). Crusting soils are typical of these dry areas, where soil degradation is induced soils by diminishing infiltration rates and increasing runoff and erosion rates (Ries and Hirt, 2008). Arid areas are considered fragile environments where vegetation cover is scarce and where soil erosion processes occur rapidly and severely after rainfall events fall in these areas. However, even under those conditions, the importance of native vegetation is very significant in the regulation of surface hydrological processes. Physical properties of soil play an important role in determining soil's suitability for agricultural, environmental and engineering uses. The supporting capability; movement, retention and availability of water and nutrients to plants; ease in penetration of roots, and flow of heat 
and air are directly associated with physical properties of the soil. Physical properties of soil include: soil texture (gravel, silt, and clay), soil structure (oblique cube, granular, plate shaped, prism-like, columnar, and oblique cube with flat edges), soil specific weight, lime and gypsum contents of soil, soil aeration, soil atmosphere, soil temperature, soil color, and soil and water interaction (Jafari and Sarmadian, 2008). Physical properties of soil is essential for defining and/or improving soil health to achieve optimal productivity for each soil/climatic condition. The physical characterization of soil in the field depends strongly on its spatial and temporal variability. If large agricultural fields are to be described successfully from the physical point of view, better ways of handling this variability have to be found. There is a strong growing realization that yields are limited by the physical conditions rather than plant nutrient status in the soil. Among many climatic and edaphic crop production constraints, substantial reduction in the production capacity of rainfed areas could be attributed to soil physical constraints like surface crusting and hardening, subsurface hard pan and compactness, high permeability, slow permeability and extremes of consistence, soil water-related constraints, wind and water erosion, etc. This envisages that for increasing crop production, soil must be maintained in such a physical condition so as to allow adequate crop growth. Unless the soil physical environment is maintained at its optimum level, the genetic yield potential of a crop cannot be realized even when all the other requirements In rainfed soils, particularly in Alfisols, Entisols and Aridisols soils, crust formation at the soil surface by the beating action of rain results in poor germination of crops, reduced infiltration and enhanced rainfall run-off (Misra, 1995).

\section{Material and Method:-}

A preliminary survey of the area was carried out for the collection of basic information regarding vegetation and physiographic locations etc. Surface $(0-15 \mathrm{~cm})$ and subsurface $(15-30 \mathrm{~cm})$ soil samples were collected randomly from different land uses (cultivated and pasture lands) marked with the Global Positioning System co-ordinates. All the samples were collected with stainless steel auger, spade and spatula to avoid any contamination. The soil samples were air dried, ground, passed through $2 \mathrm{~mm}$ sieve and finally stored in cloth bags.

Soil tests were done for $\mathrm{pH}$, texture, BD and WHC at soil testing laboratory, Post Graduate Soil laboratory CSKHPKV, Palampur by using following respective methods:

1. $\mathrm{pH}$ by standard $\mathrm{pH}$ meter in a 1:2 soil-water suspension.

2. Soil texture (sand, silt and clay) by international pipette method (Piper, 1950).

3. Bulk density (BD) by weighing bottle method (Lutz, J.F. 1947).

4. Water holding capacity (WHC) by Keen's box method (Piper, 1950).

Table1:- Surface area of soil affects its physical properties and is largely determined by amount of clay present in soil:

Specific surface area of soil particles

\begin{tabular}{|c|c|c|c|c|}
\hline Particle & Effective Diameter $(\mathbf{c m})$ & Mass $(\mathbf{g})$ & Area $\left(\mathbf{c m}^{2}\right)$ & Specific Surface Area $\left(\mathbf{c m}^{2} \mathbf{g}^{-1}\right)$ \\
\hline Gravel & $2 \times 10^{-1}$ & $1.13 \times 10^{-2}$ & $1.3 \times 10-1$ & 11.1 \\
\hline Sand & $5 \times 10^{-3}$ & $1.77 \times 10^{-7}$ & $7.9 \times 10-5$ & 444.4 \\
\hline Silt & $2 \times 10^{-4}$ & $1.13 \times 10^{-11}$ & $1.3 \times 10-7$ & $11.1 \times 104$ \\
\hline Clay & $2 \times 10^{-4}$ & $8.48 \times 10^{-15}$ & $6.3 \times 10-8$ & $7.4 \times 106$ \\
\hline
\end{tabular}

(Fall, 2000).

\section{Results and Discussion:-}

In present study, a little variation in clay and almost no variation in sand and silt contents was observed (Table 2 and 3 ) in Spiti soils of high altitude cold desert which have been originated from weathered rocks. They are immature and have large proportion of sand, gravel and stone in them (Dwivedi et al. 2005) indicating the dominance of sand forming minerals in parent materials. Hence, our findings indicated that the cold arid soils are dominated by sand alike the hot arid soils, and this relative high proportions of sand in these soil fragments is causing sandy loam textural class in this region. Sand fraction varied from 39 to 65 per cent in surface and 40 to 64 per cent in subsurface horizons of cultivated lands (annual crops), 38 to 60 per cent in surface and 42 to 65 per cent in subsurface layers of cultivated lands (apple plantation) and 44 to 56 in surface and 43 to 62 per cent in subsurface horizons of pasture lands of Spiti valley (Table 2 and 3). Silt content in surface soils of cultivated lands (annual crop), cultivated lands (apple plantation) and pasture lands varied from 19 to 45, 24 to 40 and 22 to 35 per cent, respectively whereas, in the sub-surface soils it ranged from 17 to 43, 25 to 30 and 16 to 31 per cent in respective land uses. Under cultivated lands (annual crop), cultivated lands (apple plantation) and pasture lands the clay content 
ranged from 8 to 26,10 to 21 and 15 to 20 per cent, respectively in surface soils whereas, in subsurface soils it ranged from 7 to 22,7 to 16 and 14 to 23 in respective land uses. The texture of soils of Spiti valley was found to be sandy loam, loam and sandy clay loam (Sharma and Kanwar 2010). WHC varied from 18.7 to 35.1, 20.1 to 32.3 and 10 to 33.7 in surface and 18.7 to $39.9,19.3$ to 29.1 and 8 to 28.9 per cent in subsurface layers of cultivated lands (annual crop), cultivated lands (apple plantation) and pasture lands, respectively (Babhulkar et al. 2000; Selvi et al. 2005). Pasture lands were found to have comparatively lower WHC as compared to cultivated lands (annual crops) because of higher clay and organic matter content in cultivated lands (annual crops). Soil pH in surface soils varied from 7.2 to $8.3,7.7$ to 7.9 and 7.6 to 8.1 in surface and 7.1 to $8.1,7.5$ to 7.8 and 7.5 to 7.9 in subsurface under cultivated lands (annual crops), cultivated lands (apple plantation) and pasture lands, respectively. Majority of soils were moderately alkaline in reaction. The $\mathrm{pH}$ of cultivated lands (annual crops) was observed tending towards neutrality and comparatively low as compared to pasture lands because of amelioration effect due to regular addition of FYM to annual crops (Parmar et al. 1999). Bulk density in the surface soils under cultivated lands (annual crops), cultivated lands (apple plantation) and pasture lands varied from 1.20 to $1.37,1.25$ to 1.28 and 1.23 to $1.38 \mathrm{Mgm}^{-3}$, whereas, in the subsurface layers, it varied from 1.20 to $1.55,1.23$ to 1.28 and 1.17 to $1.26 \mathrm{Mgm}^{-3}$, respectively (Sharma and Kanwar 2010).

Table 2:-Range and mean values of physical properties in surface $(0-15 \mathrm{~cm})$ soils under different land uses in Spiti valley

\begin{tabular}{|c|c|c|c|c|c|c|}
\hline & \multicolumn{3}{|c|}{ Mechanical separates (\%) } & \multirow{2}{*}{$\begin{array}{c}\text { BD } \\
\left(\mathrm{Mgm}^{-3}\right) \\
(\mathrm{w} / \mathrm{w})\end{array}$} & \multirow{2}{*}{$\begin{array}{c}\text { WHC } \\
(\%)\end{array}$} & \multirow[t]{2}{*}{$\mathbf{p H}$} \\
\hline & Sand & Silt & Clay & & & \\
\hline \multicolumn{7}{|c|}{ Cultivated lands (annual crops) } \\
\hline Range & $39-65$ & $19-45$ & $8-26$ & $1.20-1.37$ & $18.7-35.1$ & $7.2-8.3$ \\
\hline Mean & 49 & 29 & 19 & 1.27 & 27.27 & 7.69 \\
\hline SD士 & 5.2 & 5.7 & 3.9 & 0.05 & 4.09 & 0.17 \\
\hline \multicolumn{7}{|c|}{ Cultivated lands (apple plantation) } \\
\hline Range & $38-60$ & $24-40$ & $10-21$ & $1.25-1.28$ & $20.1-32.3$ & $7.7-7.9$ \\
\hline Mean & 51 & 28 & 14 & 1.27 & 26.47 & 7.77 \\
\hline SD士 & 10.2 & 7.8 & 4.9 & 0.02 & 5.6 & 0.09 \\
\hline \multicolumn{7}{|c|}{ Pasture lands } \\
\hline Range & $44-56$ & $22-35$ & $15-20$ & $1.23-1.38$ & $10-33.7$ & $7.6-8.1$ \\
\hline Mean & 50 & 30 & 17 & 1.29 & 21.35 & 7.75 \\
\hline SD士 & 4.8 & 4.9 & 1.8 & 0.05 & 10.02 & 0.18 \\
\hline
\end{tabular}

Table 3:- Range \& mean values of physical properties in subsurface soils $(15-30 \mathrm{~cm})$ under different land uses in Spiti valley

\begin{tabular}{|c|c|c|c|c|c|c|}
\hline & \multicolumn{3}{|c|}{ Mechanical separates (\%) } & BD & \multirow{2}{*}{$\begin{array}{c}\text { WHC } \\
(\%)\end{array}$} & \multirow[t]{2}{*}{$\mathbf{p H}$} \\
\hline & Sand & Silt & Clay & $\left(\mathrm{Mg} \mathrm{m}^{-3}\right) \quad(\mathrm{w} / \mathrm{w})$ & & \\
\hline \multicolumn{7}{|c|}{ Cultivated lands (annual crops) } \\
\hline Range & $40-64$ & $17-43$ & $7-22$ & $1.20-1.55$ & $18.7-39.9$ & $7.1-8.1$ \\
\hline Mean & 54 & 28 & 15 & 1.27 & 27.62 & 7.6 \\
\hline SD士 & 5.73 & 5.79 & 4.42 & 0.06 & 4.66 & 0.16 \\
\hline \multicolumn{7}{|c|}{ Cultivated lands (apple plantation) } \\
\hline Range & $42-65$ & $25-30$ & $7-16$ & $1.23-1.28$ & $19.3-29.1$ & 7.5-7.8 \\
\hline Mean & 57 & 28 & 10 & 1.25 & 23.02 & 7.7 \\
\hline SD士 & 10.42 & 2.16 & 4.04 & 0.02 & 4.24 & 0.14 \\
\hline \multicolumn{7}{|c|}{ Pasture lands } \\
\hline Range & $43-62$ & $16-31$ & $14-23$ & $1.17-1.26$ & $8-28.9$ & $7.5-7.9$ \\
\hline Mean & 54 & 25 & 19 & 1.27 & 17.93 & 7.7 \\
\hline SD士 $_{ \pm}$ & 7.06 & 5.77 & 3.34 & 0.07 & 8.25 & 0.17 \\
\hline
\end{tabular}

\section{Acknowledgement:-}

The authors are highly thankful to Soil Science Department CSK H.P.K.V, Palampur, Soil PG Lab assistant for heartfelt help and coordinal support in guiding the authors in a right direction. 


\section{Literature Cited:-}

1. Babhulkar, P.S., Wandile, R.M., Badole, W.P and Balpande, S.S. 2000. Residual effect of long-term application of FYM and fertilizers on soil properties (Vertisols) and yield of soybean. Journal of the Indian Society of Soil Science 48(1): 89-92

2. Cornelis, W.M. 2006. Hydroclimatology of wind erosion in arid and semiarid environments. Chapter Dry land Ecohydrology, D’Odorico and A. Porporatopp 141-159.

3. D’Odorico., P. and Porporato, A. 2006. Ecohydrology of arid and semiarid ecosystems: an introduction. Dry land Ecohydrology, P.D’Odorico and A. Porporatopp 1-10

4. Dregne, H.E. 1976. Soils of arid regions. Developments in soil science pp 40-45

5. Dwivedi, S.K., Sharma, V.K and Bharadwaj, V. 2005. Status of available nutrients in soils of cold arid Ladakh. Journal of the Indian Society of Soil Science 53: 421-423

6. Jafari, M. and Sarmadian, F. 2008. Fundamentals of Soil Sciences and Soil Classification, Second Edition, Tehran: Publications of University of Tehran pp176-201

7. Fall, H. 2000. Spatial variability of overland flow in a small arid basin and specific surface area of soil particles. IAHS Publ. 189, 105-120

8. Lutz JF. 1947. Apparatus for collecting disturbed soil samples. Soil Science 64: 399-401

9. Misra, A. N. 1995. Seedling emergence and growth under crust. J. Environ. Biol. 113-117

10. Parmar, D.K., Sharma, V., Sharma, K.D. and Sharma, T.R. 1999. Micronutrient status of vegetable growing pocket in cold desert areas of Himachal Pradesh. Journal of the Indian Society of Soil Science 47(2):280-283

11. Piper, C.D. 1950. Soil and Plant Analysis. Inc. Sci. Pub. INC, New York pp123

12. Ries., J.B. and Hirt, U. 2008. Permanence of soil surface crusts on abandoned farmland in the central Ebro Basin/Spain. Catena, 72, 282-296

13. Salih, A.A. 1998. Root and shoot growth of Prosopischilensis in response to soil impedance and soil matric potential. Journal of arid environments. 40, 43-52

14. Selvi, D., Santhy, P and Dhakshinamoorthy, M. 2005. Effect of inorganics alone and in combination with farmyard manure on physical properties and productivity of Vertic-Haplustepts under long-term fertilization. Journal of the Indian Society of Soil Science 53(3): 302-307

15. Sharma, V., and Kanwar, B.B. 2010. Copper status and its relation with soil properties in pea growing soils of high hills dry temprate zone of Himachal Pradesh. Indian Journal of Agricultural Research 44(1): 32-37 